\title{
Organized recreational fishing in school, knowledge about nature and influence on outdoor recreation habits
}

\author{
Jonas Ahnesjö ${ }^{1}$ (D) Tom Danielsson ${ }^{1}$
}

Published online: 1 August 2020

(C) The Author(s) 2020

\begin{abstract}
In this study we have investigated the effectiveness of a one day school-based intervention with recreational fishing (in Swedish called Klassdraget) in increasing environmental awareness, interest in nature and recreational fishing in pupils aged between 8 and 12. Our results suggest a weak positive association between exposure to natural environments in a recreational fishing context and interest in nature and recreational fishing. We found the intervention to have no effect on the frequency of fishing, interest in fishing more, or number of visits in nature during spare time. Knowledge about nature and possibly also environmental awareness are positively affected and these effects can be traced as long as three years after the intervention. Our findings also reveal a low correlation between frequency of nature visits and selfreported interest in nature. The observed effects of Klassdraget are small but appear to be larger for girls, who are traditionally less interested in recreational fishing when compared with boys.
\end{abstract}

Keywords Schoolchildren · Intervention · Outdoor recreation · Interest for nature - Natural awareness $\cdot$ Recreational fishing

\section{Introduction}

The increasing focus on environmental problems such as global warming has led to governments across the world encouraging attempts to change attitudes and behaviours among citizens to become more environmentally aware and friendly. However, much research in the area has focused on adults and there is a lack of knowledge on what and how environmentally friendly behaviour and attitudes are formed in children (Evans

Jonas Ahnesjö

Jonas.ahnesjo@lnu.se

1 Faculty of social science, Department of sport science, Linnaeus University, Växjö, Sweden 
et al., 2007). Outdoor recreation and led outdoor experiences are often used in different programs aimed at personal development and behaviour change in youth. Consequently, many of these interventions are not suitably designed to allow scientific evaluation. Thus, the majority of studies concerning the effects of such efforts present anecdotal evidence and therefore the possibilities to draw causal conclusions are limited (see e.g. Williams et al., 2018).

Interventions in schools are appealing because if they are effective they provide a method for reaching a large number of children of a specific age. Numerous school interventions aiming to change behaviours and attitudes have been conducted over recent years. Often, these interventions lack a proper study design and are consequently often poorly evaluated which makes it hard to draw conclusions about their effectiveness. Early life experiences of natural environments and outdoor activities, some occurring in pre-school and early school years, have been suggested as ways to increase connectedness to nature and even promote environmentalism in adulthood (Wells \& Lekies 2006, Kals et al., 1999). Chawla (1998) argued that outdoor experiences (such as outdoor recreation activities) are a major factor influencing responsible environmental behaviour. Outdoor activities that are often mentioned in this context are camping, hiking, hunting and fishing (Tanner 1980; Wells \& Lekies 2006). Recreational fishing is an important leisure activity in Sweden with 1.8 million people (approximately $20 \%$ of the population) participating in some kind of recreational fishing during 2007 (Eriksson 2008). Recreational fishers span all ages with a peak in the age class 1624 with predominantly male practitioners (Eriksson 2008, Norling 1995 and Norlin 2008). According to Granek et al. (2008) recreational fishing is a popular outdoor activity with an average participation rate of approximately $10 \%$ worldwide.

Recreational fishing may not only serve as a mediator of environmentally friendly behaviour (Chawla 1998), but it also has ethical implications concerning, for instance, animal welfare (e.g., Cooke and Sneddon, 2006). Ethical concerns about fishing are important and likely to affect motivation for fishing and thus also participation rates. However, although these questions are important, ethical considerations are not specifically addressed in this study. Our study concerns: (1) the effectiveness of a one-day intervention with fishing in school to support participation in fishing and interest in nature; and (2) the outdoor and recreational fishing habits among Swedish schoolchildren.

The major question asked in this study relates to an intervention focused on organized recreational fishing in school, and its possible effectiveness in increasing interest in nature, natural awareness and outdoor recreation in Swedish schoolchildren. We quantitatively explore the hypothesis that organized recreational fishing in school may positively affect interest in recreational fishing, nature and outdoor recreation amongst Swedish schoolchildren and their environmental awareness. We specifically focus on an intervention known as Klassdraget in Swedish, which translates as (the class fishing lure) in English (Sportfiskarna [The Swedish Anglers Association], 2015).

Klassdraget is financially supported by the Swedish Environmental Protection Agency (Naturvårdsverket) and managed by the Swedish Federation of Recreational Fisheries (Sportfiskarna) and the Swedish Federation of Hunting (Svenska Jägareförbundet). Klassdraget is voluntary and individual teachers in elementary schools throughout Sweden may apply to participate in the intervention. If a class is accepted for participation, a local angling club will take the class fishing for one day. Klassdraget has pedagogical aims and strives to increase environmental awareness, 
interest in nature and outdoor recreation, more specifically for recreational fishing. A resource package, containing some literature and suggestions for the leaders on how to carry out the intervention, is also included. Approximately 15,000 elementary school pupils participated in Klassdraget between 2006 and 2009.

\section{Methods}

\section{Participants}

Our investigation worked with a sample of elementary school pupils from 8 to 12 years of age, some of whom participated in the Klassdraget intervention, while others were positioned in a control group. The intervention group (hereafter referred to as the Klassdraget group) consisted of 276 individuals from 8 to 12 years ( $n_{\text {girls }}=114$ and $\left.\mathrm{n}_{\text {boys }}=162\right)$ from 17 classes; and the control group consisted of 133 individuals of the same age $\left(\mathrm{n}_{\text {girls }}=70\right.$ and $\left.\mathrm{n}_{\text {boys }}=71\right)$ from 10 classes.

The control group consisted of children in classes parallel to the classes for the Klassdraget group (i.e. children of the same age) in the same schools. However, some schools did not have more than one class in the same age group, or did not distribute the questionnaire to parallel classes. Thus, the number of individuals and classes in the control group ( $\left.\mathrm{n}_{\text {classes }}=10\right)$ is lower than in the Klassdraget group $\left(\mathrm{n}_{\text {classes }}=17\right)$. We received a list of contact persons (including e-mail addresses) for all schools that have participated in Klassdraget over the last few years from Sportfiskarna. The list contained 112 names of teachers from approximately 100 different schools. All schools on the list were initially contacted by e-mail and the schools that agreed to participate in this study received the questionnaires with instructions by mail a short time after.

The schools involved (i.e. all schools that accepted to participate in this study) were located across Sweden, from the far north to the far south, in a variety of communities, from small villages to big cities. Due to limitations in relation to the study design, including ethical considerations, we decided not to collect demographic information in this investigation.

\section{Procedure}

The questionnaires created for this study were the same for both the control group and the Klassdraget group in most respects, however the Klassdraget-group answered additional questions concerning the actual activities during the day of participation in Klassdraget. Questionnaires were sent as paper-copy mail to the responding schools in February 2011 and were returned during spring of the same year. Because the actual date for when pupils completed their questionnaire was not recorded on the returned questionnaires, we used the first day of March 2011 as a reference date when testing for effects over time following participation in Klassdraget.

The questions occurring in both questionnaires concerned outdoor recreation habits in general and recreational fishing habits in particular (how often, with whom and if the respondents would like to fish and/or spend more time in natural environments more often). As a proxy for environmental awareness (see Kals et al., 1999) we asked both groups to quantify their general interest in nature in a four-point Likert scale (I am not 
at all interested, I am somewhat interested, I am fairly interested, and I am very interested). We have no information on if and how the resource package was used during the intervention and therefore we will not consider this in our analysis.

\section{Ethical considerations}

This study follows the ethical recommendations produced by the Swedish Research Council (2017). Data concerning location and names of schools remain confidential and were not used in analysis. However, these parameters are known to influence outdoor behaviours (for example Arlinghaus, et al., 2008). Names of individual teachers and pupils are not included in the questionnaires and, hence, all these persons are anonymous. Furthermore, all questionnaires were followed by a letter explaining the purpose and voluntary nature of this study. Written consent from parents was administrated by the individual schools.

\section{Statistical analyses}

Tests for effect of participation in Klassdraget was performed using the chi-squared $\left(\chi^{2}\right)$ test. In the cases where expected counts (the product of the corresponding row and column totals in the contingency table divided by the sample size) were below 5 , Fisher's exact test was used because the chi-square test is unreliable when the number of observations is low. Both tests (chi-squared and Fischer exact) were used in order to test for differences in proportions in the different answers by comparing observed counts with expected counts (assuming that distribution of the answers are random) between, for example, the Klassdraget group and the control group and/or genders. Correlation analyses were performed in order to test for possible linear associations between two variables (e.g. time since participation in Klassdraget and self-estimated interest in nature). Because data did not meet the assumptions for parametric analyses, all tests were performed using non-parametric statistics (chi-square, Fisher exact and Spearman's rank correlation).

Despite the limitations of the control group characteristics created by the smaller number of classes involved, we performed analyses using the Klassdraget group and control group as nondependent variables; but we only considered these results as mere indications of possible associations. Because boys do fish in higher frequencies (Eriksson 2008, Norling 1995, 2008), they are also likely to be in possession of more specific knowledge about fishing. Based upon that assumption, we explored whether girls who participated in recreational fishing increase their knowledge of the activity more than the boys who participated. Thus, we also tested for differences between the sexes. All statistical analyses were performed using the IBM Statistical Package for the Social Science (SPSS) Statistics 20.

\section{Limitations}

The unbalanced design of the study in relation to numbers of classes in each group (Klassdraget and control) did not allow us to perform any meaningful pairwise tests between classes within the schools. This is a limitation because the effect of confounders associated with the school (location, teachers, etc.) likely had an influence on 
the results of this study. Thus, we have been careful not to draw any major conclusions based upon comparisons between the groups. The number of classes in this study constitutes a small proportion of the total number of classes initially contacted (17 out of 112). It is possible that this may have impacted our results, but the fact that it was the teachers and not the pupils who choose not to respond to our request positions this risk as one we consider to be of minor importance. All the above-mentioned limitations inevitably affect interpretation of our results. Any generalizations to a larger population should be made with great care.

\section{Results}

This results section is divided into two parts. The first part reports the analysis of the fishing habits of the participants; the second part is focused on the participant's relationships with nature. The majority of the participants $(73 \%)$ responded that they sometimes fish during their spare time and there was no significant difference between the Klassdraget group and the control group $\left(\chi^{2}, p=0.40\right)$. In total, 126 participants $(47 \%)$ reported that they learned something they did not already know about nature by participating in Klassdraget. There was a significant difference between boys and girls in this regard with $36 \%$ of the boys and $57 \%$ of the girls stating that they learned something they did not already know about nature $\left(\chi^{2}, p<0.001, n=269\right)$.

\section{Fishing habits}

Do you fish during your spare time? The total number of children who reported fishing during their spare time was $294(73 \%)$; and there was no significant difference between the Klassdraget group $76 \%(n=202)$ and the control group $69 \%\left(\chi^{2}, p=0.40\right)$. The number of boys who fished was significantly higher in both the Klassdraget group (boys 78\%, $n=126$ and girls $67 \%, n=76, \chi^{2}, p=0.042$ ) and the control group (boys $82 \%, n=51$ and girls $59 \%, n=41, \chi^{2}, p=0.003$ ). There was, however, no significant difference between the Klassdraget group and the control group in frequencies of girls and boys fishing during their spare time $\left(\chi^{2}, n s\right)$.

In total, 112 individuals (27\%) stated that they do not fish at all. However, only 102 of these answered the question whether they would like to fish during their spare time if given the opportunity. In total $23.5 \%$ ( $n=24,10$ girls and 14 boys) of the "non fishers" answered that they would like to fish.

Frequency of fishing. Frequency of fishing was estimated using a four-point scale: "> once a week," "once a week $\geq$ once a month," "a few times a year," and "less than once a year." The klassdraget group did not fish more than the control group $\left(\chi^{2}, p=\right.$ $0.11)$. When analysing the sexes separately no difference could be detected between the boys (Fisher exact, $p=0.18$ ) and the girls (Fisher exact, $p=0.84$ ) in each group. Boys fish significantly more often than do the girls in both the Klassdraget group $\left(\chi^{2}\right.$, $p<0.001$ ) and in the control group (Fisher's exact, $p=0.03$ ).

Of the 291 participants that answered the question, "Would you like to fish more often?" there were 202 who would like to fish more often than they currently do. There was no difference between the Klassdraget group and the control group $\left(\chi^{2}, p=0.3\right)$. Within the control group there was a significant difference between the sexes, with the 
boys answering that they would like to fish more than they already do to a higher degree than the girls $\left(\chi^{2}, p<0.048\right)$. There was a close to significant difference between the sexes in this question in the pooled dataset $\left(\chi^{2}, p=0.051\right)$. The boys tended to want to fish more often than they already do to a higher degree when compared with the girls, with $74 \%(n=175)$ and $62 \%(n=116)$ for the boys and girls respectively.

Fishing companions. In the pooled dataset (Klassdraget group and control group together), $89 \%$ fished with someone in their family, $26 \%$ fished with friends, $2.6 \%$ fished with a fishing club/organisation and $8 \%$ fished alone. Note that multiple responses were possible and hence the total exceeds $100 \%$.

When comparing the sexes in the pooled dataset the girls fished more with family members than did the boys $(96 \%$ as compared to $84 \%)\left(\chi^{2}, p=0.001\right)$. Boys fished more often with friends $\left(\chi^{2}, p=0.002\right)$ than did the girls $(32.6 \%$ as compared to $16.1 \%$ ). No girls and $3.9 \%$ of the boys fished with a fishing club/association (fisher exact, $p=0.044$ ) and $12.9 \%$ of the boys and only $0.9 \%$ of the girls fished with no companion $\left(\chi^{2}, p<0.0001\right)$ (Table 1$)$.

The proportion of children fishing alone in the Klassdraget group was $11 \%(n=23)$ and in the control group $1 \%(n=1)$. Proportions of individuals fishing with friends was $30 \%(n=62)$ and $16 \%(n=15)$ for the Klassdraget group and the control group respectively $\left(\chi^{2}, p=0.01\right)$. No differences could be detected between the groups in the proportion of individuals fishing with someone in their own family or with an organisation, such as a fishing club (Table 1).

\section{Nature}

Self-reported interest in nature. Interest in nature was self-reported using a four-point scale: "not at all interested," "somewhat interested," "interested," and "very interested." There was no difference in interest in nature between the Klassdraget group $(n=255)$ and the control group $(n=117)\left(\chi^{2}, p=0.093\right)$. When the responses were analysed by collecting across different parts of the scale, combined sets of responses did reveal significant difference between the control group and the Klassdraget group $\left(\chi^{2}, p=\right.$ 0.03 ), with $52 \%$ of the Klassdraget group reporting that they were interested or very interested in nature, as compared to the control group which had $40 \%$ answering that they are somewhat or very interested in nature.

Correlation between degree of nature interest and time since participation in Klassdraget. There was a weak but significant positive correlation between the number of months since participation in Klassdraget and the self-reported interest in nature (Spearman correlation $=0.135, p=0.037$ ). The time between filling out the questionnaire and participation in Klassdraget ranged from 6 to 35 months. This result, indirectly, indicated that duration of the effects may exceed 35 months (approximately 3 years). In an attempt to separate a possible effect of increasing age of the respondents from the putative effect of participation in Klassdraget we performed a correlation analysis between age of respondent and self-reported interest in nature for the pooled data (control and Klassdraget groups). This analysis revealed that, if anything, interest in nature appeared to decrease with age (Spearman correlation $=-0.1, p=0.042$ ).

Correlation between frequency of fishing and degree of nature interest. In order to test if participation in outdoor recreation activities (recreational fishing) was accompanied by increased interest in nature, we tested for a positive correlation between fishing 
Table 1 Fishing Companions among Swedish Schoolchildren who Participated in the Klassdraget Group and the Control Group

Fishing companions

\begin{tabular}{|c|c|c|c|c|}
\hline & Family(\%) & Friends $(\%)$ & Org.(\%) & Alone(\%) \\
\hline \multicolumn{5}{|c|}{ Klassdraget and control (pooled genders) } \\
\hline & 89 & 26 & 3 & 8 \\
\hline \multicolumn{5}{|c|}{ Klassdraget and control (by gender) } \\
\hline Boys & 84 & 33 & 0 & 13 \\
\hline Girls & 96 & 16 & 4 & 1 \\
\hline$p$ & $<0.001$ & $<0.01$ & $<0.05^{*}$ & $<0.0001$ \\
\hline
\end{tabular}

Klassdraget $v$ s control (pooled genders)

$\begin{array}{lllll}\text { klassdraget } & 89 & 34 & 3 & 11 \\ \text { control } & 90 & 16 & 1 & 1 \\ p & n s & <0.05 & n s & <0.01\end{array}$

Klassdraget $v$ s control (by gender)

Boys

$\begin{array}{lllll}\text { Klassdraget } & 84 & 38 & 5 & 17 \\ \text { control } & 84 & 20 & 2 & 2 \\ p & n s & <0.05 & n s & <0.01\end{array}$

Girls

$\begin{array}{lllll}\text { Klassdraget } & 96 & 18 & 0 & 0 \\ \text { control } & 98 & 12 & 0 & 1 \\ p & n s & n s & & n s\end{array}$

Within groups (by gender)

Klassdraget

$\begin{array}{lllll}\text { boys } & 84 & 20 & 2 & 2 \\ \text { girls } & 98 & 12 & 0 & 0 \\ p & <0.05 & \text { ns } & \text { ns } & \text { ns }\end{array}$

control

$\begin{array}{lllll}\text { boys } & 84 & 38 & 5 & 17 \\ \text { girls } & 96 & 18 & 0 & 11 \\ p & n s & n s & n s & <0.01\end{array}$

*Fisher exact test

Note. Multiple answers were possible; hence the totals do not sum up to $100 \%$. "Org" means organisation such as an angling club or similar

frequency and self-reported interest in nature. There were, however, no significant correlations either in the pooled data (Klassdraget and control groups) (Spearman correlation $=0.09, \mathrm{~ns})$, or in the Klassdraget group (Spearman correlation $=0.1, \mathrm{~ns}$ ) or the control group (Spearman correlation $=0.03$, ns) when analysed separately.

Spending time in nature. No significant difference was found between the Klassdraget group and the control group $\left(\chi^{2}, p=0.58\right)$ in relation to spending time in nature during time when participants had some discretion over what they chose to do, 
with $11 \%$ of the individuals (pooled data) stating that they never visited nature during their spare time. There was no difference between the Klassdraget group (10\%) and the control group (12\%) on this question. The main reasons for not spending free time in nature were in descending order "not interested" $(n=18)$, "other reason" $(\mathrm{n}=12)$, "too time consuming" $(n=9)$, and "lack of companions" $(n=6)$.

Nature visiting frequency was estimated using a four-point scale, as mentioned earlier: "> once a week," "once a week $\geq$ once a month," "a few times a year," and "less than once a year." The girls in the Klassdraget group visited nature more frequently than the girls in the control group $\left(\chi^{2}, p=0.008\right)$. No differences were found among the boys $\left(\chi^{2}, p=0.46\right)$.

Nature visit companions. Only in the group stating that they sometimes visit nature alone was there a significant difference between the Klassdraget group $(25 \%, n=60)$ and the control group $(15 \%, \mathrm{n}=17)\left(\chi^{2}, p=0.035\right)$. In the pooled dataset (Klassdraget and control groups), $60 \%$ visited nature with someone in their own family, $66 \%$ with friends, $6 \%$ with a club/organisation and $22 \%$ alone. Note that multiple answers could be given by each individual and hence the total exceeds $100 \%$. When comparing the sexes in the pooled dataset the girls visited nature more with family members than did the boys $\left(66 \%\right.$ as compared to $\left.55 \%, \chi^{2}, p=0.045\right)$ and the boys visited nature alone to a higher degree when compared to the girls, with $29 \%$ of the boys and $13 \%$ of the girls visiting nature alone $\left(\chi^{2}, \mathrm{p}=0.001\right)$. A summary is presented in Table 2 .

Correlation between frequency of nature visits and interest for nature. There was a significant but low level positive correlation within the Klassdraget group between frequency of visits in nature and interest for nature (Spearman correlation $=0.15$, $p<0.05$ ). This correlation was positive and moderate also in the control group (Spearman correlation $=0.35, p<0.01)$. In the pooled data (Klassdraget and control groups) there was a low level positive correlation between frequency of visits in nature and interest for nature (Spearman correlation $=0.23, \mathrm{p}=0.01$ ). Taken together, these results suggest that a higher degree of self-reported interest in nature is accompanied with a somewhat higher frequency of nature visits in both groups.

\section{Discussion}

\section{Recreational fishing habits}

Our result shows that 126 individuals (47\%) responded that they learned something they did not already know about nature by participating in Klassdraget. Interestingly, the girls appear to have learned new things about nature to a higher degree than the boys. The reason for this may originate in the fact that the girls are generally less interested in fishing (Eriksson 2008; Norling 2008) and their "new" knowledge could perhaps be considered quite basic from the perspective of some of the boys. Exactly what their new nature knowledge consists of is unclear, however, as this question was not included in the questionnaire. Regardless, this result suggests that the intervention appears to have had the desired effect, especially for the girls, as increased knowledge about nature was one of the goals of the intervention.

The finding that no less than $73 \%$ of the participants responded that they sometimes fish during their spare time corresponds well with the results from a survey conducted in 2007 by 
Table 2 Nature Visit Companions among Swedish Schoolchildren who Participated in the Klassdraget Group and the Control Group

Nature visit companions

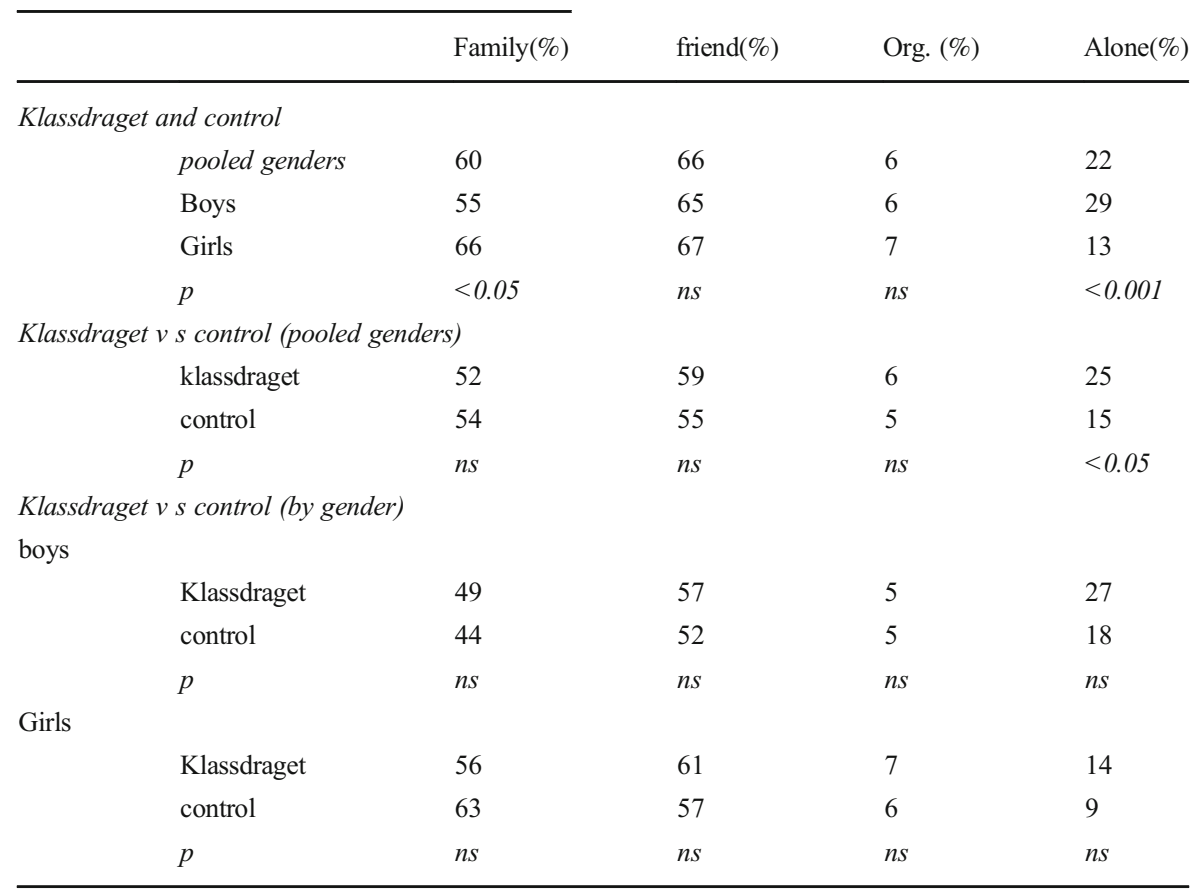

Note. Multiple answers were possible; hence the totals do not sum up to $100 \%$. "Org" means organisation such as an outdoor leisure club or similar

Norlin (2008), wherein 69\% of the 10-15 year olds surveyed claimed that they had fished sometime during the previous year. When these results are compared with those results from another survey conducted by Norling (1995) in 1995, the number of young people fishing appears to be somewhat lower in 2007. However, Norlin (2008) argues that due to methodological weaknesses in the survey from 1995, this comparison should not be used to draw conclusions. Nevertheless, results from 1995 at least indicate that there may be a trend of decreasing interest in recreational fishing in Sweden. Demographic distribution of recreational fishers in Sweden spans all age groups with a peak amongst 16-24 year olds (Eriksson, 2008). Our investigation concerns a rather small sample of young people in the age range of 8-12 years, some of whom have participated in the Klassdraget intervention; hence, this does not allow direct comparison in relation to total recreational fishing frequencies in Sweden. Yet it could be said that recreational fishing is an important leisure activity for youth in Sweden.

As reported in several studies (Eriksson 2008, Norling 1995, 2008) the number of boys fishing is higher than the number of girls fishing. This difference between the sexes in frequency of fishing is also seen among the boys and girls that do fish during their spare time, with boys fishing significantly more often than do the girls. Degree of fishing interest may be reflected 
in who one decides to go fishing with (if anyone). If one decides to fish alone it is likely that the interest in recreational fishing is strong and boys are overrepresented in this group, again showing that boys are generally more interested in fishing. Alternatively, fishing alone may be motivated by an individual's need for being alone. If fishing occurs with a fishing club or organization it is likely that a genuine interest in fishing motivates participation, and again only the boys appear to do this. Similarly, if one goes fishing with friends this may reflect a genuine interest for fishing, however not as strongly as if one goes fishing alone, as the social aspects of fishing may be important or even more important. If fishing occurs only with family members it may be that affiliation with family is the primary reason for fishing. Again, the observed sex differences in interest for recreational fishing is supported by our results, as the girls fish significantly more often with family members than do the boys, possibly suggesting that girls may fish more for social reasons.

It is noteworthy that interest in recreational fishing among young girls appears to be increasing in popularity over recent years (Eriksson 2008, Norling 2008), suggesting that recreational fishing may become an activity shared between the sexes.

Although boys appear to be more interested in fishing than girls, this is not very clear in the $27 \%(n=112)$ that did not and would not fish at all during their spare time, even if given the opportunity, 24\% ( $n=24,10$ girls and 14 boys) stated that they would like to fish. These results are supported by the 2007 survey by Norling (2008) in which $23 \%$ of the non-fishers stated that they would like to fish if given the opportunity. Approximately $20 \%(n=88)$ claim that they would not fish even if they were given the opportunity and this probably reflects the proportion who are simply not interested in recreational fishing as an activity. This is supported by the result that the main reason for not spending free time in nature is lack of interest.

The fact that there was no difference in recreational fishing frequencies between the Klassdraget group and the control group suggests that the Klassdraget intervention did not have an effect in this respect. However, there was a positive effect of Klassdraget on nature visiting frequency. Although this difference may only be ambiguously assigned to participation in Klassdraget, it indicates that Klassdraget does have some effect. Alternative explanations may include other factors, such as a motivating teacher, geographic location, and availability of fishing opportunities (Wells and Lekies 2006, Chawla 1998). Consequently, we conclude that participation in Klassdraget appears to be accompanied by a higher frequency of nature visits during spare time and that the causes of this remain to be examined in more detail.

Of the 291 participants who answered the question about whether they would like to fish more often, 202 would like to fish more often than they already do, suggesting that recreational fishing has potential to increase visits in natural environments; and this has been shown to have positive effects on human health and wellbeing (Berman, et al., 2008; Groenewegen et al., 2006; Hansmann, et al., 2007, Hartig et al., 2003; Korpela, et al., 2010; Maas et al., 2006; Mitchell and Popham 2008; Tenngart Ivarsson and Hagerhall 2008; Ulrich, 1984; Velarde et al., 2007). These results also suggest that recreational fishing (at least when it comes to the number of potential practitioners) may be under explored and utilized as a way to further engage young people with nature. This potential is, however, limited to an economical and health point of view, as there are no ecological considerations taken in this analysis. 


\section{Recreational fishing, nature interest and outdoor habits}

The Klassdraget group was generally more interested in nature, as compared to the control group, again showing that the Klassdraget intervention may have had the desired effect in this respect. Interestingly, the duration of the effect appears to exceed several years as the correlation analysis showed that there was a positive correlation (low but significant) between time since participation in Klassdraget and self-reported nature interest. We expected that the effect of the Klassdraget intervention should decrease with time since participation and that this would result in a negative correlation. Instead, interest for nature and possibly also nature awareness appeared to increase with time after participation in the intervention. A possible explanation for this may be that the Klassdraget intervention was the "spark that lit the fire" of interest in nature and that this was a logical outcome of increased knowledge of nature. This is in part supported by the idea of "significant life experiences" (Tanner 1980, Chawla 1998). Alternatively, this result may simply be a consequence of age, whereby interest in nature and natural awareness may increase with age. However, we find no support for the latter either in the literature or in the fact that there was a low but negative correlation between age and interest in nature in the pooled data (which in fact indicates the opposite).

Despite the observed differences between the groups in self-reported interest in nature, this is not manifest in the frequency of nature visits amongst the boys, but amongst the girls. The results from the correlation analyses reveal that there was a very low (but significant) positive correlation between self-reported interest in nature and frequency of nature visits (in both the Klassdraget and the control groups) but no significant correlation between self-reported interest in nature and frequency of recreational fishing. These results may be considered surprising, as one may intuitively think that a high frequency of visits to natural environments reflects a genuine interest in nature and that outdoor activities, such as recreational fishing, are accompanied with a certain measure of nature interest (Bögennholtz et al., 2006; Wolf-Watz et al., 2011). Instead, this finding may reflect a current trend in outdoor recreation described by Arnegård (2006), suggesting that nature is used as an arena for activities rather than being visited for traditional recreation. If so, it is interesting that this view of nature is present already in the young pupils who participated in this study. Another explanation may be that outdoor recreators simply are not more interested in nature than nonoutdoor recreationists (Beery 2013).

The differences between the two groups (Klassdraget and control) reported above may or may not originate in participation in Klassdraget per se. Differences may be a result of the teachers inspiring the pupils or possibly a combination of teacher inspiration and participation in Klassdraget. As noted above, Klassdraget is an initiative engaged with by the teachers which may eventually culminate in a class fishing trip, and it is reasonable to think that the teachers involved are dedicated to recreational fishing, nature and environmental issues and that these teachers are more focused on environmental concerns even outside the Klassdraget intervention. This, however, does not necessarily confound our results in a significant way, but raises some new questions. One such question is the role of teacher and other adult inspiration, such as leaders in sports and recreation, when it comes to interest in nature and environmental issues in youth. In the review by Chawla (1998) both the "teacher effect" and outdoor experiences are acknowledged as important factors influencing environmental interest, concern and action. 


\section{Conclusions}

By way of our study, Klassdraget appears to have had some modest positive effect on interest in nature, participation in recreational fishing, and knowledge about recreational fishing and nature. Duration of these significant but small effects may be traced at least 35 months after participation in the intervention. The observed effects appear to be somewhat stronger in the girls, probably because recreational fishing is male biased. Recreational fishing is a major leisure activity among youth in Sweden and appear to have potential to be incorporated in school as a learning agent for knowledge about nature and possibly also environmental issues. Our results may also suggest that gender biased activities, such as recreational fishing (male biased), in school may be beneficial for learning. However, if conclusions are to be drawn from an educational intervention like Klassdraget, it is important to separate the effects of the intervention per se from other factors such as an inspiring teacher. Furthermore, in order to examine the duration of any observed effect of interventions in more detail, large scale longitudinal studies are required.

Funding Information Open access funding provided by Linnaeus University.

Open Access This article is licensed under a Creative Commons Attribution 4.0 International License, which permits use, sharing, adaptation, distribution and reproduction in any medium or format, as long as you give appropriate credit to the original author(s) and the source, provide a link to the Creative Commons licence, and indicate if changes were made. The images or other third party material in this article are included in the article's Creative Commons licence, unless indicated otherwise in a credit line to the material. If material is not included in the article's Creative Commons licence and your intended use is not permitted by statutory regulation or exceeds the permitted use, you will need to obtain permission directly from the copyright holder. To view a copy of this licence, visit http://creativecommons.org/licenses/by/4.0/.

\section{References}

Arlinghaus, R., Bork, M., \& Fladung, E. (2008). Understanding the heterogeneity across an urban-rural gradient in a metropolitan area (Berlin, Germany), with implications for fisheries management. Fisheries Research, 92(1), 53-62.

Arnegård, J. (2006). Upplevelser och lärande i äventyrssport och skola. Doctoral thesis, HLS förlag 2006, Stockholm.

Beery, T. H. (2013). Nordic in nature: Friluftsliv and environmental connectedness. Environmental Education Research., 19(1), 94-117.

Berman, M. G., Jonides, J., \& Kaplan, S. (2008). The cognitive benefits of interacting with nature. Psychological Science, 19(12), 1207-1212.

Bögenholtz, S. (2006). Nature experience and its importance for environmental knowledge, values and action: Recent German empirical contributions. Environmental Education Research, 12(1), 65-84.

Chawla, L. (1998). Significant experiences revisited: A review of research on sources of environmental sensitivity. Environmental Education Research, 4(4), 369-382.

Cooke, S. J., \& Sneddon, L. U. (2006). Animal welfare perspectives on recreational angling. Applied Animal Behaviour Science, 104(3-4), 176-198.

Eriksson, T. (2008). Recreational fishing in Sweden. In Øystein Aas (Ed.) Global challenges in recreational fisheries (pp.43-47). Oxford: Blackwell Publishing.

Evans, G. W., Brauchle, G., Haq, A., Stecker, R., Wong, K., \& Shapiro, E. (2007). Young Children's attitudes and behaviours. Environment and Behavior, 39(5), 635-659.

Granek, E. F., Madin, E. M. P., Brown, M. A., Figueira, W., Cameron, D. S., Hogan, Z., Kristianson, G., De Villiers, P., Williaims, J. E., Post, J., Zahn, S., \& Arlinghaus, R. (2008). Engaging recreational fishers in management and conservation: Global case studies. Conservation Biology, 22(5), 1125-1134. 
Groenewegen, P. P., van den Berg, A. E., de Vries, S., Robert, A., \& Verheij, R. A. (2006). Vitamin G: Effects of green space on health, well-being, and social safety. BMC Public Health, 6, 149.

Hansmann, R., Hug, S.-M., \& Seeland, K. (2007). Restoration and stress relief through physical activities in forests and parks. Urban Forestry \& Urban Greening, 6, 213-225.

Hartig, T., Evans, G. W., Jamner, L. D., Davis, D. S., \& Garling, T. (2003). Tracking restoration in natural and urban field settings. Journal of Environmental Psychology, 23(2), 109-123.

Kals, E., Schumacher, D., \& Montada, L. (1999). Emotional affinity toward nature as a motivational basis to protect nature. Environment and Behaviour, 31(2), 178-202.

Korpela, K. M., Ylen, M., Tyrvainen, L., \& Silvennoinen, H. (2010). Favorite green, waterside and urban environments, restorative experiences and perceived health in Finland. Health Promotion International, 25(2), 200-209.

Maas, J., Verheij, R. A., Groenewegen, P. P., de Vries, S., \& Spreeuwenberg, P. (2006). Green space, urbanity, and health: How strong is the relation? Journal of Epidemiology and Community Health, 60(7), 587-592.

Mitchell, R., \& Popham, F. (2008). Effect of exposure to natural environment on health inequalities: An observational population study. The Lancet, 372(9650), 1655-1660.

Norlin, J. (2008). Barn och ungdomars fiskevanor [Children and young people's fisging habits]. Sweden: Sveriges Sportfiske- och Fiskevårdsförbund.Retrieved from https://www.mynewsdesk. $\mathrm{com} / \mathrm{material} /$ document $/ 2656 /$ download?resource type=resource_document

Norling, I. (1995). Barn och ungdomars sportfiske. Fiskeriverket: Göteborg.

Sportfiskarna [The Anglers]. (2015). Klassdraget. Retrieved from https:/www.sportfiskarna.se/KlassDraget

Swedish Research Council. (2017). Good research practice. Retrieved from https://www.vr. se/download/18.5639980c162791bbfe697882/1555334908942/Good-Research-Practice_VR_2017.pdf

Tanner, T. (1980). Significant life experiences: A new research area in environmental education. Journal of Environmental Education, 11(4), 20-24.

Tenngart Ivarsson, C., Hagerhall, C., \& M. (2008). The percieved restorativeness of gardens - assessing the resotativeness of a mixed built and natural scene type. Urban Forestry \& Urban Greening, 7, 107-118.

Ulrich, R. S. (1984). View through a window may influence recovery from surgery. Science, 224, 420-421.

Velarde, M. D., Fry, G., \& Tveit, M. (2007). Health effects of viewing landscapes - landscape types in environmental psychology. Urban Forestry \& Urban Greening, 6, 199-212.

Wells, N. M., \& Lekies, K. S. (2006). Nature and the life course: Pathways from childhood nature experiences to adult environmentalism. Children, Youth and Environments, 16(1), 1-24.

Williams, I. R., Rose, L. M., Raniti, M. B., Waloszek, J., Dudgeon, P., Olsson, C. A., Patton, G. C., \& Allen, N. B. (2018). The impact of an outdoor adventure program on positive adolescent development: A controlled crossover trial. Journal of Outdoor and Environmental Education, 21, 207-236.

Wolf-Watz, D., Sandell, K., \& Fredman, P. (2011). Environmentalism and tourism preferences: A study of outdoor recreationists in Sweden. Scandinavian Journal of Hospitality and Tourism, 11(2), 190-204.

Publisher's note Springer Nature remains neutral with regard to jurisdictional claims in published maps and institutional affiliations.

Jonas Ahnesjö is a senior lecturer and researcher in outdoor recreation and biology at the department of sport science, Linnaeus University, Sweden. Main areas of research includes health effects of outdoor recreation, recreational fishing, outdoor recreation behaviour, and environmental awareness.

Tom Danielsson is a lecturer in sport science at the department of sport science, Linnaeus University, Sweden. Research interests are outdoor recreation and learning and physiological effects of extreme endurance sports. 